\title{
MENINGKATKAN HASIL BELAJAR MATEMATIKA DENGAN METODE THINK PAIR SHARE PADA MATERI TURUNAN
}

\author{
Andy Sapta \\ Program Pendidikan Matematika, Universitas Asahan \\ e-mail : khayla2000@yahoo.com
}

\begin{abstract}
Abstrak
Tujuan penelitian tindakan kelas ini adalah untuk meningkatkan hasil belajar siswa pada materi turunan dengan menggunakan metode think pair share. Untuk mencapai tujuan tersebut peneliti mengubah pembelajaran dengan konvensional dengan menggunakan think pair share. Data penelitian ini diperoleh dari observasi terhadap siswa, dan hasil tes evaluasi siswa. Dari hasil dua siklus diperoleh peningkatan nilai rata-rata hasil belajar siswa pada materi turunan sebesar 66,8 pada siklus pertama menjadi 76,8 pada siklus kedua dan ketuntasan klasikal sebesar 73,7\% pada siklus pertama menjadi 86,8\% pada siklus kedua. Dapat disimpulkan bahwa model pembelajaran think pair share layak untuk diterapkan dalam proses pembelajaran turunan di SMA Harapan 1 Medan.
\end{abstract}

Kata Kunci : turunan, think pair share

\section{PENDAHULUAN}

Pendidikan merupakan media yang sangat berperan untuk menciptakan manusia yang berkualitas dan berpotensi dalam arti yang seluas-luasnya, melalui pendidikan akan terjadi proses pendewasaan diri sehingga di dalam proses pengambilan keputusan terhadap suatu masalah yang dihadapi selalu disertai dengan rasa tanggung jawab yang besar. Mengingat peran pendidikan tersebut maka sudah seyogyanya aspek ini menjadi perhatian pemerintah dalam rangka meningkatkan sumber daya masyarakat Indonesia yang berkualitas.

Matematika sebagai salah satu mata pelajaran di sekolah dinilai cukup memegang peranan penting dalam membentuk siswa menjadi berkualitas, karena matematika merupakan suatu sarana berpikir untuk mengkaji sesuatu secara logis dan sistematis. Karena itu, maka perlu adanya peningkatan mutu pendidikan matematika. Salah satu hal yang harus diperhatikan adalah peningkatan prestasi belajar matematika siswa di sekolah.

Dalam pembelajaran di sekolah, matematika merupakan salah satu mata pelajaran yang masih dianggap sulit dipahami oleh siswa. Oleh karena itu dalam proses pembelajaran matematika diperlukan suatu metode mengajar yang bervariasi. Artinya dalam penggunaan metode mengajar tidak harus sama untuk semua pokok bahasan, sebab dapat terjadi bahwa suatu metode mengajar tertentu cocok untuk satu pokok bahasan tetapi tidak untuk pokok bahasan yang lain. Kenyataan yang terjadi adalah 
penguasaan siswa terhadap materi matematika masih tergolong rendah jika dibanding dengan mata pelajaran lain.

Kondisi seperti ini terjadi pula pada SMA Harapan 1 Medan, bahwa penguasaan materi matematika oleh siswa masih tergolong rendah. Salah satu materi matematika yang penguasaan siswa rendah adalah pada pokok bahasan Turunan. Pada materi tersebut banyak siswa pada tahun sebelumnya yang belum mampu menyelesaikan soal dengan baik. Hal ini dapat dilihat dari rata-rata hasil belajar matematika siswa pada materi Turunan pada tahun pembelajaran tahun silam.

Rendahnya hasil belajar matematika siswa dipengaruhi oleh berbagai faktor, di antaranya adalah model pembelajaran yang digunakan oleh guru. Hasil analisi awal peneliti menunjukan bahwa pembelajaran matematika di SMA Harapan 1 Medan masih menggunakan model pembelajaran yang kurang tepat atau konvesional yakni suatu model pembelajaran yang banyak didominasi oleh guru, sementara siswa duduk secara pasif menerima informasi pengetahuan dan keterampilan. Hal ini diduga merupakan salah satu penyebab siswa menjadi merasa jenuh dan malas mengikuti pelajaran matematika sehingga menurunkan prestasi belajar matematika siswa.

Melihat fenomena tersebut, maka perlu diterapkan suatu sistem pembelajaran yang melibatkan peran siswa secara aktif dalam kegiatan belajar mengajar, guna meningkatkan hasil belajar matematika disetiap jenjang pendidikan. Salah satu model pembelajaran yang melibatkan peran siswa secara aktif adalah model pembelajaran kooperatif. Model pembelajaran kooperatif sangat cocok diterapkan pada pembelajaran matematika karena dalam mempelajari matematika tidak cukup hanya mengetahui dan menghafal konsep-konsep matematika tetapi juga dibutuhkan suatu pemahaman serta kemampuan menyelesaikan persoalan matematika dengan baik dan benar. Melalui model pembelajaran ini siswa dapat mengemukakan pemikirannya, saling bertukar pendapat, saling bekerja sama jika ada teman dalam kelompoknya yang mengalami kesulitan. Hal ini dapat meningkatkan motivasi siswa untuk mengkaji dan menguasai materi pelajaran matematika sehingga nantinya akan meningkatkan hasil belajar matematika siswa.

Melihat penguasaan siswa terhadap materi matematika khususnya pokok bahasan Aljabar, maka dalam penelitian ini model pembelajaran yang dipilih adalah model pembelajaran kooperatif tipe Think Pair Share (berpikir berpasangan). Think Pair Share (berpikir berpasangan) merupakan jenis pembelajaran kooperatif yang dircancang untuk mempengaruhi pola interaksi siswa (Trianto, 2010: 81). Dengan pemilihan model ini, diharapkan pembelajaran yang terjadi dapat lebih bermakna dan memberi kesan yang kuat kepada siswa.

\section{Metode Pembelajaran Think Pair Share}

Think Pair Share (berpikir berpasangan) merupakan suatu cara yang efektif untuk membuat variasi suasana diskusi kelas, dengan asumsi bahwa semua resitasi atau diskusi membutuhkan pengaturan untuk mengendalikan kelas secara keseluruhan, dan prosedur yang digunakan dalam Think Pair Share dapat memberi siswa lebih banyak waktu berpikir, untuk merespon dan saling membantu, Trianto (2010: 81).

Langkah-langkah yang digunakan dalam pembelajaran Think Pair Share menurut Trianto (2010: 81-82) adalah sebagai berikut: 
a. Langkah 1: Berpikir (Thingking)

Guru menjelaskan suatu pertanyaan atau masalah yang dikaitkan dengan pelajaran, dan meminta siswa menggunakan waktu beberapa menit untuk berpikir sendiri jawaban atau masalah. Siswa membutuhkan penjelasan bahwa berbicara atau mengerjakan bukan bagian berpikir.

b. Langkah 2: Berpasangan (Pairing)

Selanjutnya guru meminta siswa untuk berpasangan dan mendiskusikan apa yang telah mereka peroleh. Interaksi selama waktu yang disediakan dapat menyatukan jawaban jika suatu pertanyaan yang diajukan atau menyatukan gagasan apabila suatu masalah khusus yang diidentifikasi.

c. Langkah 3: Berbagi (Share)

Pada langkah akhir, guru meminta pasangan-pasangan untuk berbagi dengan keseluruhan kelas yang telah mereka bicarakan. Hal ini efektif untuk berkeliling ruangan dari pasangan ke pasangan dan melanjutkan sampai sekitar sebagaian pasangan mendapat kesempatan untuk melaporkan.

Dengan demikian, teknik ini memberi siswa kesempatan untuk belajar sendiri serta bekerja sama dengan orang lain, keuntungan lain dari metode ini adalah optimalisasi partisipasi siswa, (Lie, 2008: 57).

\section{METODE}

Subyek penelitian ini adalah siswa kelas XI IPA 1 SMA Harapan 1 Medan. Rincian kegiatan penelitian ditempuh dalam dua siklus dengan perincian: (1) Perencaaan, penelitian menetapkan kompetensi dasar dan indikator yang akan dicapai pada penelitian tindakan kelas, menyusun rencana pelaksanaan penelitian, menyusun instrumen observasi untuk proses pembelajaran dan proses pembelajaran; (2) Pelaksanaan penelitian, peneliti menggunakan Think Pair Share dalam proses pembelajaran turunan; (3) Pengamatan/observasi, peneliti melakukan dan mencatat semua hal yang diperlukan yang terjadi selama pelaksanaan tindakan berlangsung. Pengumpulan data dilakukan dengan menggunakan instrumen observasi yang telah disusun. Data yang dikumpulkan berupa data kuantitatif dan kualitatif; (4) Refleksi, pada tahap ini hasil siklus pertama dilakukan perbaikan pada siklus kedua.

Indikator keberhasilan penelitian ini adalah terjadinya peningkatan hasil belajar turunan dengan dicapainya nilai rata-rata hasil belajar di atas kriteria ketuntasan minimal dan secara klasikal telah tercapai $85 \%$.

Data penelitian ini adalah : (1) hasil tes evaluasi siswa, tes hasil belajar ini berbentuk essay sebanyak 10 soal yang berisi materi tentang turunan; (2) hasil pengamatan langkah pembelajaran dan suasana kelas pada saat pembelajaran berlangsung, hasil pengamatan diperoleh dari instrumen observasi yang dilakukan dengan pengamatan langsung gejala-gejala subjek di dalam situasi yang sebenarnya. 
Materi observasi terhadap siswa meliputi: (1) Memperhatikan penjelasan guru; (2) Mengerjakan soal latihan; (3) Menyelesaikan soal latihan secara mandiri; (4) Mampu menyelesaikan soal latihan dengan baik; (5) Mampu menyelesaikan soal latihan dengan cepat; (6) Bersemangat; (7) Mengikuti pembelajaran dengan tertib dan menghargai pendapat orang lain; (8) Menyimpulkan pelajaran

Pengumpulan data dilakukan dengan observasi dan perekaman proses pembelajaran, dan hasil evaluasi siswa siswa yang dilakukan setiap akhir siklus berlangsung. Pelaksanaan observasi dilakukan oleh seorang observer dengan sistem penilaian didasarkan pada 3 (tiga) kategori yaitu: "kurang (skor: 0 - 30,0)", "sedang (skor: 30,1 - 70,0)", "baik (skor: 70,1 - 100)". Analisis data mencakup tiga kegiatan yang dilakukan secara bersamaan, yaitu (1) reduksi data, (2) penyajian data, dan (3) penarikan simpulan/verifikasi.

\section{HASIL DAN PEMBAHASAN}

Siswa memang sering melakukan kerja kelompok, tapi hanya kerja kelompok biasa dalam mengerjakan pekejaan di rumah. Berdasarkan hasil observasi dan hasil refleksi pada siklus I hasilnya antara lain masih kurangnya keterampilan guru menerapkan metode pembelajaran. Hal ini disebabkan karena metode ini merupakan metode yang baru pertama kali diterapkan dalam pembelajaran matematika oleh guru dan diterima oleh siswa, namun hal ini tidak terlalu mengganggu proses kegiatan pembelajaran.

Kurangnya kemampuan guru dalam mengelola kelas disebabkan guru masih beradaptasi terhadap keadaan siswa serta dalam melakukan penyebaran perhatian ke siswa kurang begitu maksimal, sering kali guru hanya memperhatikan siswa yang di depan kelas saja. Selain itu, guru dalam mengajukan pertanyaan masih mengundang jawaban serentak dari siswa, dan pertanyaan juga terlalu mudah sehingga banyak siswa yang bisa menjawabnya. Guru juga tidak mengarahkan pertanyaan untuk siswa tertentu, tetapi untuk seluruh siswa.

Selain dari faktor guru, juga terdapat faktor siswa yang belum terbiasa dan belum begitu paham. Hal ini tampak bahwa sebagian siswa kurang teliti dalam mengerjakan soal latihan. Peneliti juga menemukan siswa yang cepat menyerah ketika mereka mengerjakan soal yang agak rumit atau agak beda dari contoh yang diberikan guru, walaupun ketika diterangkan mereka bilang sudah paham. Untuk mengatasi hal ini, guru selalu memotivasi mereka untuk selalu aktif bertanya jika belum paham. Dengan memotivasi itulah siswa menjadi bersemangat untuk mengerjakan soal dan aktif bertanya apabila ada kesulitan, sehingga semua tugas dapat terselesaikan dengan baik.

\section{Siklus I}

Hasil belajar pada siklus I, rata-rata nilai siswa adalah 66,8. Sedangkan persentase siswa yang mendapat nilai lebih dari 65 adalah $73,7 \%$ dan persentase siswa yang mendapat nilai kurang dari 65 adalah 26,3\%, hal ini belum sesuai harapan yaitu persentase siswa yang mendapat nilai lebih dari 65 minimal $85 \%$.

Hasil pengamatan terhadap guru terlihat guru kurang memahami potensi sebenarnya yang dimiliki oleh siswa, guru juga sering mengukur kemampuan siswa menggunakan standar melebihi realitas. Intensitas guru dalam memberikan bimbingan 
kepada siswa secara kelompok masih kurang mencukupi. Guru masih mendominasi kegiatan belajar-mengajar. Padahal seharusnya siswalah yang aktif, oleh karena itu guru harus berusaha mendorong dan memotivasi agar terciptanya kegiatan pembelajaran yang aktif. Guru kurang terampil dalam menerapkan Think Pair Share dalam pembelajaran. Untuk itu guru harus mempelajari Think Pair Share, sehingga bisa lebih terampil dalam menerapkan model ini di kelas.

Hasil pengamatan terhadap aktivitas siswa pada umumnya siswa cukup aktif mengikuti proses pembelajaran, tetapi masih ada beberapa siswa (8-10 siswa) yang kurang antusias mengikuti jalannya pembelajaran. Oleh karena itu guru harus sesering mungkin melakukan tanya jawab kepada siswa, terutama yang mempunyai aktivitas rendah dan mendapat nilai di bawah 65. Masih sedikit siswa yang berani mengemukakan pertanyaan. Siswa yang berani bertanya ada 15 siswa. Untuk mengatasi hal itu guru selalu memotivasi mereka untuk selalu aktif bertanya jika belum paham. Dengan motivasi itulah siswa menjadi aktif bertanya apabila ada kesulitan, sehingga semua tugas dapat terselesaikan dengan baik.

Karena target pencapaian ketuntasan belajar belum sesuai dengan yang diharapkan maka perlu dilanjutkan pada siklus kedua.

\section{Sikilus II}

Ketika pembelajaran dengan menggunakan Think Pair Share di siklus I hal ini terlihat semakin meningkat yaitu sebanyak $73,7 \%$ atau 28 orang yang dinyatakan tuntas belajar. Akan tetapi hal ini masih belum membuat penelitian ini berhasil sehingga dilanjutkan pada siklus II. Pada siklus II, setelah tindakan diberikan menunjukkan hasil belajar siswa yang meningkat menjadi rata-rata hasil belajar siswa 76,8 dan termasuk dalam kriteria sukses yaitu sebanyak 33 orang atau $86,8 \%$ dari jumlah siswa yang dinyatakan tuntas.

Hasil pengamatan terhadap guru terlihat guru sudah memahami potensi sebenarnya yang dimiliki oleh siswa, seringnya guru mengadakan tanya jawab yang mengarah pada materi pelajaran. Intensitas guru dalam memberikan bimbingan kepada siswa secara kelompok sudah mencukupi. Guru sudah tidak tergesa-gesa dalam menyelesaikan materi, sehingga siswa yang lambat dapat mengikuti dan meningkat motivasinya. Guru dalam menjelaskan metode Think Pair Share sudah maksimal.

Hasil pengamatan terhadap aktivitas siswa pada umumnya siswa cukup aktif mengikuti proses pembelajaran, tetapi masih ada beberapa siswa (3-5 siswa) yang kurang antusias mengikuti jalannya pembelajaran. Oleh karena itu guru harus sesering mungkin melakukan tanya jawab kepada siswa, terutama yang mempunyai aktivitas rendah. Siswa yang mengajukan pertanyaan semakin bertambah yaitu ada 20 siswa. Hasil evaluasi pada siklus II persentase ketuntasan belajar siswa sudah maksimal. Ada peningkatan beberapa siswa tetapi masih ada 3 siswa yang nilainya di bawah 65 .

\section{SIMPULAN DAN SARAN}

Simpulan: Think Pair Share layak digunakan dalam proses pembelajaran turunan, karena dapat meningkatkan penguasaan siswa terhadap hasil belajar matematika khususnya pada materi turunan pada kelas XI IPA 1 SMA Harapan 1 Medan. 
Saran: Diharapkan guru-guru di SMA Harapan 1 Medan khususnya dan guru-guru Matemtika pada umumnya agar menggunakan Think Pair Share dalam proses pembelajaran dalam upaya meningkatkan hasil pembejaran pada materi tersebut.

\section{DAFTAR PUSTAKA}

Arends, Richard. I. 2008. Learning to Teach. Edisi Indonesia (diterjemahkan oleh Helly Prajitno Soetjipto \& Sri Mulyantini Soetjipto). Yogyakarta. Pustaka Pelajar.

Arikunto, Suharsimi dkk. 2009. Penelitian Tindakan Kelas. Jakarta: Bumi Aksara.

Baharuddin dan Wahyuni. 2008. Teori Belajar dan Pembelajaran. Jogjakarta. Ar-Ruzz Media.

Dimyati and Mudjiono, 2006. Belajar dan Pembelajaran. Jakarta. Rineka Cipta.

Iskandarwassid. 2008. Strategi Pembelajaran Bahasa. Bandung: Remaja Rosdakarya.

Lie, Anita. 2008. Mempraktekan Cooperative Learning di Ruang-ruang Kelas. Jakarta: Grasindo.

Nasution, S. 2008. Berbagai Pendekatan dalam Proses Belajar dan Mengajar. Jakarta: Bumi Aksara.

Sardiman, 2009. Interaksi dan Motivasi Belajar Mengajar. Jakarta. RajaGrafindo Persada.

Siahaan, Amiruddin,. dkk. 2006. Manajemen Pengawas Pendidikan. Ciputat: Quantum Teaching.

Sudjana, Nana. 2009. Penilaian Hasil Proses Belajar Mengajar. Bandung: Remaja Rosdakarya.

Supardi. dkk. 2009. Penelitian Tindakan Kelas. Jakarta: Bumi Aksara.

Syah, Muhibbin. 2009. Psikologi Belajar.Jakarta: Rajagrafindo Persada.

Trianto. 2010. Mendesain Model Pembelajaran Inovatif-Progresif: Konsep, Landasan, dan Implementasinya pada Kurikulum Tingkat Satuan Pendidikan (KTSP). Jakarta: Kencana Prenada Media Group.

Wena, Made. 2009. Strategi Pembelajaran Inovatif Kontemporer Suatu Tinjauan Konseptual Operasional. Jakarta: Bumi Aksara.

Wiriaatmadja, Rochiati. 2007. Penelitian TIndakan Kelas. Bandung. Remaja Rosdakarya. 